\title{
SENJATA KAUM LEMAH: PERLAWANAN SEHARI-HARI PETAMBAK GARAM
}

\author{
Yety Rochwulaningsih
}

\author{
Departemen Sejarah Fakultas Ilmu Budaya \\ Universitas Diponegoro
}

Alamat korespondensi:wulan@undip.ac.id

Diterima/ Received: 4 Juli 2016 ; Disetujui/ Accepted: 1 Agustus 2016

\begin{abstract}
This article examines how the salt farmer's weapon in their resistance against the life's oppressive conditions and why this resistance model lead in their everyday life that tipically vulnerable helpless in many ways. It is studied with using of historical method that emphasizes on oral history. For collecting data and observation purposes, it is equipped with qualitative analysis. The results showed that the Indonesian salt farmers, especially in Java has a quirk resistance, which tends to be soft, closed, and not frontal, but it continuously takes place in their productive activity daily rhythm. It is taken because they do not have bargaining power with other parties both in economic, social, cultural and political.
\end{abstract}

Keywords: resistance, salt farmer, the weak party.

\section{Abstrak}

Tulisan ini mengkaji bagaimana senjata kaum lemahdari komunitas petambak garam dalam melakukan perlawanan terhadap kondisi yang menekan kehidupannya dan mengapa mereka menempuh model perlawanan sehari-hari tipical dilakukan kaum lemah yang dalam banyak hal tidak berdaya. Untuk mengkaji itu digunakan metode sejarah yang menekankan pada oral history dalam proses pengumpulan datanya dan dilengkapi observasidengan analisis kualitatif. Hasil penelitian menunjukkan, bahwa petambak garam di Indonesia khususnya di Jawa memiliki kekhasan dalam melakukan perlawanan, yaitu cenderung lunak, tertutup dan tidak frontal, tetapi berlangsung secara kontinu dalam ritme aktivitas produktif mereka sehari-hari. Hal itu ditempuh, karena mereka cenderung tidak memiliki posisi tawar dengan pihak lain baik secara ekonomi, sosial budaya maupun politik.

Kata Kunci: perlawanaan, petambak garam, kaum lemah.

\section{PENDAHULUAN}

Dalam khasanah historiografi Indonesia, petambak garam yang memproduksi garam sebagai komoditastidak mendapatkan perhatian yang memadai jika dibandingkan dengan pelaku usaha yang memproduksi berbagai jenis tanaman komoditas lainnya. Hal ini antara lain dapat diketahui belum maraknya hasil-hasil penelitian yang dilakukan ahli sejarah maupun ahli lainya seperti sosiologi, ekonomi, politik dan antropologi. Meskipun demikian, telah ada beberapa pioner studi historis mengenai masyarakat petambak garam di Indonesia, seperti Gerrit J. Knaap (1991: 
127-157) yang menganalisis bagaimana para elite di Jawa kehilangan kontrol atas produksi garam di pantai utara Jawa selama abad XVII-XVIII dan kontrol terhadap produksi maupun perdagangan garam pada akhirnya jatuh ke tangan VOC dan orang-orang Cina. Demikian juga pada masa kolonial Belanda yang dengan sangat strik mengendalikan produksi dan perdagangan garam melalui kebijakan monopoli oleh pemerintah (Departemen van Binnenlandsch Bestuur, 1932; Sanders, 1968;).

Agak berbeda kajian yang dilakukan oleh Hub de Jonge yang mencoba mengaitkan monopoli garam oleh pemerintah kolonial Belanda dengan munculnya berbagai perlawanan masyarakat pembuat garam di Madura (de Jonge, 1993: 165-184). Ketika pada 1917 pemerintah kolonial Belanda menempuh kebijakan "membeli ladang-ladang garam penduduk pribumi" untuk memproduksi garam secara besar-besaran dan produksi maupun perdagangan dimonopoli pemerintah, maka mulai muncul protes dan perlawanan dari petani garam terutama di Madura. Kondisi yang bernuansa semakin meluasnya gerakan protes dan perlawananpetani secara berani dan terbuka yang dilakukan masyarakat Madura kepada pemerintah kolonial Belanda, sangat terkait dengan keberadaan dan agitasi politik masif oleh berbagai organisasi nasionalis yang meluaskan pengaruhnya di kalangan petani pedesaan (Kuntowijoyo, 1988). Dalam konteks ini pengaruh Syarikat Islam sangat besar terhadap petani garam di Madura dalam memprovokasi maupun mengorganisasi gerakan-gerakan protes dan perlawanan terhadap pemerintah kolonial Belanda (de Jonge, 1993: 165-184).

Dari kajian yang dilakukan de Jonge tersebut, dapat diketahui bahwa benih-benih protes dan beragam bentuk perlawanan di kalangan petambak garam telah ada terutama ketika menghadapi situasi dan kondisi yang sangat menekan kehidupan mereka. Gerakan perlawanan semakin menunjukkan eskalasi yang tinggi ketika masuk pengaruh dari luar terutama yang bersifat politis dan ideologis. Kondisi Indonesia kontemporer, konflik terbuka di kalangan petambak garam masih juga terjadi terutama yang terkait dengan penguasaan dan legalitas lahan yang dikerjakan para petambak dan itu terutamaterjadi di Madura (Effendy, 2012; Fitriya, 2012). Konflik petambak garam di Madura lebih bersumber dari legalitas penguasaan lahan di mana para petambak yang telah mengerjakan lahan tambak secara turun temurun justru dari aspek legalitas tidak lagi sebagai pihak yang mengusai lahan, karena penguasaan lahan berada di pihak PT. Garam yang merupakan Badan Usaha Milik Negara. Oleh karena itu, konflik terjadi antara petambak garam dengan pihak PT. Garam dan hal ini sudah berlangsung berpuluh puluh tahun belum ada penyelesaian secara tuntas.

Kondisi agak berbeda terjadi di luar Madura, karena menunjukkan kecenderungan yang berbeda di mana jarang ditemukan gerakan protes dan perlawanan dari petambak garam yang bersifat terbuka dan konfrontatif. Meskipun demikian, bukan berarti mereka menerima saja atau pasrah terhadap segala bentuk penindasan dan kesewenang-wenangan yang mereka terima. Sejalan dengan hal itu relevan dan menarik temuan Scott (1983) di desa "Sedaka" dan "Dataran Muda" Malaysia, bahwa kaum proletar (mean of productioness) pedesaan karena tidak memiliki sumberdaya, maka salah satu tipikal perlawanan sehari-hari yang biasa mereka lakukan adalah menghindarkan konfrontasi yang masif dan menantang serta cenderung melakukan penghindaran maupun penyamaran yang sama masifnya. Dalam konteks ini perlawanan petambak garam memiliki kecenderungan menyerupai apa yang ditemukan oleh Scott tersebut, yaitu berupa perlawanan sehari-hari yang menghindarkan konfrontasi dan cenderung melakukan penghindaran maupun penyamaran. Bertitik tolak dari latar belakang tersebut, maka tulisan ini mengaji bagaimana senjata kaum lemah dari 
komunitas petambak garam dalam melakukan perlawanan terhadap kondisi yang menekan kehidupannya dan mengapa mereka menempuh model perlawanan sehari-hari tipikal dilakukan kaum lemah yang secara ekonomi, sosial, budaya dan politik tidak berdaya?

\section{METODE}

Penelitian ini menggunakan metode sejarah yang didukung observasidalam pengumpulan data dengan pendekatan sosiologi. Metode sejarah digunakan untuk mengungkap historical aspect dari munculnya bentuk perlawanan sehari-hari sebagai senjata kaum lemah para petambak garam penggarap dan buruh angkut garam, sedangkan pendekatan sosiologi digunakan untuk dapat memahami dan menganalisis bentuk-bentuk perlawanan kolektif dari petambak garam penggarap dan buruh angkut garam beserta pola yang terbentuk dan motif-motif yang mendasari bentuk perlawanan tersebut. Perlawanan petambak garam merupakan realitas aktual yang bersifat sosiologis, tetapi pada dasarnya persoalan itu sebenarnya merupakan hasil dari proses sejarah. Oleh karena itu fenomena sosiologis itu tidak dapat semata-mata dikaji dari perspektif aktual kekinian tetapi juga harus didekati dengan perspektif historis. Pengkajian persoalan aktual dengan pendekatan historis memiliki kelebihan dalam hal kejelasan baik struktur maupun prosesualnya. Oleh karena itu tidak mengherankan jika C. Wright Mills berpendapat "Every social science or better, every well considered social studyrequires an historical scope of conception and a full use of historical material" (Skocpol, 1984).

Untuk pengumpulan data digunakan metode sejarah yang menekankan pada oral history dan dilengkapi observasi. Menurut Garraghan (1957), metode sejarah merupakan seperangkat aturan dan prinsip yang sistematis untuk mengumpulkan sumber-sumber sejarah secara efektif, menilainya secara kritis, dan menyajikan sintesa hasil-hasil yang dicapai dalam bentuk tertulis. Sementara itu Gottschalk mendefinisikan metode sejarah sebagai proses menguji dan menganalisis secara kritis rekaman dan peninggalan masa lampau (Gottschalk, 1986: 32). Dalam menerapkan metode sejarah ini ada empat langkah, yaitu; (1) Heuristik (pengumpulan sumber/data), (2) Kritik, intern dan ekstern terhadap sumber sejarah yang diperoleh, (3) Interpretasi (analisis dan sintesis terhadap data) yang dalam konteks ini lebih menekankan pada analisis kualitatif, Historiografi atau penulisan.

\section{HASIL DAN PEMBAHASAN}

Petambak garam di Indonesia bukan merupakan entitas sosial yang bercorak homogen, karena mereka terdiri dari beragam kelompok sosial seperti petambak pemilik lahan sekaligus petambak garam, penggarap/pembuat garam, dan buruh. Dengan begitu jelas bahwa mereka terdiri dari kelompok-kelompok sosial dengan kedudukan, status, dan peran masing-masing yang berbeda satu dan lainnya. Namun demikian, antara kelompok sosial yang berbeda itu karena terlibat dalam usaha yang sama yaitu mengusahakan garam, maka mereka saling berinteraksi dan berinterrelasi dalam pola-pola tertentu yang pada akhirnya mengkonstruksi struktur sosial. Struktur sosial dapat dimaknai secara luas, yaitu tidak semata-mata ditentukan oleh faktor ekonomi sebagaimana dikemukakan Marx, tetapi juga ditentukan oleh faktor sosial politik seperti status dan kekuasaan seperti yang dikemukakan Weber. Oleh karena itu, pola-pola hubungan antar individu, antar kelompok-kelompok sosial ataupun kelas-kelas sosial dalam masyarakat selain ditentukan oleh faktor ekonomi (kepemilikan dan penguasaan sumber ekonomi) juga oleh faktor sosial politik (status sosial dan kekuasaan) (Roth \& Wittich, 1978: 941-958).

Secara faktual dapat diketahui, bahwa diantara kelompok sosial pada masyarakat petambak garam tersebutmemiliki kepentingan 
yang berbeda secara signifikan, teruma antara petambak garam pemilik lahan dengan penggarap. Oleh karena itu, dengan adanya kepentingan yang berbeda terdapat peluang untuk terjadinya konflikyang sering terjadi adalah antara kedua kelompok sosial itu. Menariknya adalah suasana konflik diantara pemilik lahan tambak garam dengan petambak garam penggarap menunjukkan adanya corak dan pola perlawanan dari pihak penggarap yang spesifik, yaitutipikal perlawanan sehari-hari yang tidak terbuka, menghindarkan konfrontasi dan cenderung melakukan penghindaran maupun penyamaran yang masif. Berikut ini akan dideskripsikan dan dianalisis bagaimana petambak garam penggarap ini melakukan perlawanan terhadap dominasi bahkan eksploitasi yang secara struktural dilakukan oleh para pemilik lahan tambak garam dengan mengambil kasus di wilayah Jawa di luar Madura.

\section{Rendahnya Komitmen pada Kualitas Garam}

Kondisi objektif menunjukkan, bahwa pada berbagai level, persoalan kualitas garam selalu menjadi isu penting yang bertendensi memunculkan dampak strategis dan mendasar terkait dengan eksistensi garam sebagai komoditi yang bernilai ekonomi. Misalnya pada level petambak garam, kualitas garam akan menentukan harga atau nilai jual, sehingga akan berdampak secara langsung terhadap keuntungan atau kerugian petambak sebagai pihak yang membuat garam. Pada level di atas petambak, kualitas garam akan menjadi ajang permainan pedagang untuk menentukan margin keuntungan yang dapat diperoleh dari komoditi garam itu. Pada level nasional, kualitas garam menjadi faktor yang menentukan untuk menjadi dasar dibuatnya berbagai kebijakan pemerintah antara lain yang terkait dengan garam seperti tentang SNI Garam, Pengaturan Impor Garam, dll. Isu penting yang terkait dengan kualitas garam yang dibuat atau diproduksi oleh petambak garam Indonesia adalah kualitas garam pada umumnyaa rendah dan oleh karena itu harga tidak kompetitif bahkan tidak dapat memasok segmen industri yang merupakan pangsa pasar terbesar. Kebijakan pemerintah, juga menempatkan garam rakyat yang merupakan garam krosok hanya sebagai garam bahan baku yang harus menjalani pemrosesan/pengolahan lanjut untuk digunakan dan itu pun hanya sebatas untuk garam konsumsi, sedangkan untuk pasar industri masih tertutup, karena belum ada transparansi dalam spesifikasi dan jumlah yang dibutuhkan.

Terdapat kecenderungan, bahwa persoalan rendahnya kualitas garam yang dibuat oleh para petambak garam Indonesia yang kemudian juga sering disebut sebagai garam rakyat, selama ini selalu lebih didasarkan karena faktor budaya dimana dalam pembuatan garam, petambak garam hanya mendasarkan pada pengetahuan dan ketrampilan tradisional yang diperoleh secara turun temurun, tidak ada inovasi dan tidak ada sentuhan teknologi moderen. Padahal kondisi faktual di lapang berdasarkan hasil penelitian di lingkungan petambak garam di Jawa kecuali Madura, dapat diketahui bahwa persoalan rendahnya kualitas garam rakyat selain karena aspek budaya yang terutama justru karena persoalan sosial ekonomi yang terkait dengan persoalan struktural. Dalam konteks ini terutama menyangkut pola hubungan produksi dalam sistem bagi hasil antara petambak garam pemilik lahan dan petambak penggarap/pembuat garam bahan baku.Pola hubungan kerja diantara kedua belah pihak ini berlangsung dalam sistem bagi hasil yang dalam prakteknya sarat dengan ketidakadilan bahkan eksploitasi.

Pihak petambak garam penggarap memiliki posisi yang lebih lemah secara sosial ekonomi dibandingkan pihak petaambak garam pemilik lahan. Pihak petambak garam penggarap cenderung lebih membutuhkan pekerjaan untuk membuat garam itu bahkan menumpukan sumber nafkah rumah tangganya pada pembuatan garam 
di lahan tambak garam yang dimiliki oleh petambak pemilik lahan. Apalagi kecenderungan di Jawa, petambak garam penggaraap lebih diposisikan hanya sebagai produsen pembuat garam, sedangkan akses pasar atas produk garam yang dihasilkan penggarap berada di pihak pemilik lahan. Dengan demikian, petambak penggaraphanya memiliki otoritas dalam pembuatan garam dan konsekuensi dari hal ini bahwa persoalan kualitas garam benar-benar berada dalam wilayah otoritas pihak penggarap. Itu berarti, jika selama ini kualitas garam rakyat secara umum masih rendah jauh di bawah standar, maka persoalan utama berada di pihak petambak garam penggarap yang notabene adalah pembuat garam. Menariknya justru mengapa petambak garam penggarap yang merupakan mayoritas dari petambak garam di Indonesia ini tidak tertarik atau minimal terdorong untuk memiliki komitmen membuat garam yang berkualitas? Temuan di lapang menunjukkan, bahwa rata-rata petambak garam penggarap merasakan (pengalaman empirik meraka) tidak ada manfaatnya membuat garam yang berkualitas, karena secara ekonomi cenderung tidak memberi keuntungan secara langsung pada mereka.

Kondisi yang berbeda pada pihak petambak garam pemilik lahan di mana pada umumnyamereka sudah memiliki kepedulian terhadap persoalan rendahnya kualitas garam dan mereka memiliki kepentingan untuk mendapatkan hasil garam yang berkualitas baik, karena hal itu dapat berpengaruh secara langsung terhadap keuntungan yang akan mereka peroleh. Oleh karena itu, hampir semua responden dari pihak petambak garam pemilik lahan menginginkan produk garam di lahan mereka yang dikerjakan pihak petambak garam penggarap dapat menghasilkan garam yang berkualitas baik, mereka berpendapat dengan kualitas yang baik akan diperoleh keuntungan yang besar. Hal itu berbeda dengan pihak petambak garam penggarap, pada umumnya mereka cenderung berpendapat sebaliknya. Mereka para petambak garam penggarap kurang berminat untuk membuat garam dengan kualitas baik, pada umumnya tidak yakin bahwa jika kualitas garamnya baik akan memberi keuntungan yang besar pada mereka. Pada umumnya mereka berpendapat, bahwa petambak garam pemilik lahan yang pasti akan mendapatkan keuntungan dari peningkatan kualitas garam yang dihasilkan para penggarap. Oleh karena itu,para petambak garam penggarap terutama dalam pola bagi hasil, cenderung kurang tertarik untuk membuat garam dengan kualitas baik sesuai yang diharapkan petambak pemilik lahan, pasar maupun pemerintah.

Adanya kecenderungan dari pihak petambak garam penggarap yang tidak responsif terhadap tuntutan kualitas garam produk mereka tentu menjadi suatu hal yang menarik dan dapat menjadi pintu masuk untuk menemukan akar permasalahan bagi rendahnya kualitas garam yang selama ini merupakan persoalan serius sektor garam rakyat di Indonesia. Padahal menurut pengakuan sebagian besar penggarap, pada dasarnya secara teknis proses pembuatan garam itu sangat sederhana, hanya membutuhkan lahan, air laut, tenaga, dan sinar matahari. Adapun untuk dapat menghasilkan garam yang berkualitas baik, perlu ditambah teknologi dan modal. Persoalannya kemudian dalam proses produksi itu yang memiliki kekuatan produksi; lahan, modal, teknologi dan pasar adalah petambak garam pemilik lahan, sedangkan petambak garam penggarap hanya memiliki tenaga. Dalam hal ini tenaga cenderung tidak dinilai penting, hanya dipandang sebagai komplemen dari kekuatan produksi dan kondisi yang demikian memiliki kemiripan dengan sistem ekonomi rumah tangga (Chayanov, 1991). Oleh karena itu,para petambak garam penggarap lebih diposisikan dalam subordinasi petambak garam pemilik lahan dan kondisi itu melahirkan dominasi pemilik lahan dalam pola hubungan produksi garam rakyat bahkan sarat nuansa eksploitasi terhadap petambak garam penggarap. Hal itu antara lain tercermin dari praktek sistem bagi hasil, misalnya 
yang menerapkan sistem maro(bagi dua/50\%:50\%) seringkali pihak petambak garam penggarap menerima sekitar $30 \%$ karena harus dipotong biaya produksi (BBM), pajak tanah (PBB), penyusutan, dll. dan masih ditambah nilai jual garam dihargai petambak garam pemilik lahan cenderung di bawah harga umum.

Persoalan yang menyangkut kualitas garam ini, petambak garam penggarap sering dihadapkan pada kondisi yang tidak menguntungkan, karena tidak ada standar penentuan kualitas garam, sehingga petambak garam pemilikcenderung subjektif yang menguntungkan pihaknya. Oleh karena itu, jika terjadi penurunan kualitas produk garam dikerjakan petambak garam penggarap, seringkali petambak pemilik lahan akan memberikan sanksi antara lain berupa pemotongan pembagian hasil lebih rendah dari yang semestinya diperoleh petambak garam penggarap. Beberapa contoh kasus yang ditemukan di lapangan menunjukkan hal yang demikian. Seperti yang dikemukakan oleh pemilik lahan tambak garam di Kabupaten Rembang Jawa Tengah, bahwa jika rendahnya kualitas garam itu karena kelalaian petambak garam penggarap yang dipandang tidak bersungguh-sungguh dalam bekerja, maka ia akan menambah pemotongan hasil garapan sekitar 3-5 \% sebagai bentuk punishment. Demikian juga berdasarkan pengalaman yang pernah dialami oleh petambak garam penggarap di kabupaten yang sama menggaraplahan milik orang lain, sering dikenakan potongan oleh petambak pemilik lahan jika hasil produk garamnya dinilai jelek. Padahal penilaian itu terkesan mengada-ada, jika dibandingkan dengan produk sesama penggarap disebelah lahan yang dikerjakannya. Adapun jumlah potongan yang biasa dikenakan karena kualitas produknya dinilai rendah, relatif besar, yaitu 7-10\% dan itu masih ditambah potongan-potongan lainnya yang adakalanya hingga mencapai $20-30 \%$ dari bagi hasil dalam sistem maro.Sebaliknya jika produk garam yang dihasilkan penggarap berkualitas baik dan secara kuantitas jumlahnya banyak, pihak pemilik lahan yang memiliki hak untuk menjual produk garam yang dihasilkan petambak penggarap, cenderung akan memberi nilai jual dengan harga yang rendah dan pemilik lahan itu yang akan membelinya sendiri. Dalam konteks ini jelas bahwa petambak garam penggarap menjadi pihak yang dirugikan bahkan tidak jarang menunjukkan fenomena sebagai pihak yang di eksploitasi oleh pihak petambak garam pemilik lahan dalam sistem bagi hasil. Dalam kondisi yang sangat menekan bahkan adakalanya dirasakan dieksploitasi tersebut, pada umumnya petambak garam penggarap cenderung tidak bisa berbuat banyak karena ketiadaan sumberdaya yang bisa dimobilisasi untuk melakukan perlawanan. Satusatunya yang dimiliki adalah otoritasnya dalam membuat garam, maka tampaknya hal ini yang kemudian dijadikan senjata untuk melakukan perlawanan terhadap pihak petambak garam pemilik lahan. Hal itu bisa terjadi, karena tindakan yang bersifat ekonomi tidak selalu semata-mata dipengaruhi oleh faktor yang berdimensi ekonomi melainkan juga dimensi sosial (Granovetter, 1985).

Dalam konteks tindakan perlawanan ini,petambak garam penggarap tidak menempuh model perlawanan secara terbuka dan konfrontatif terhadap petambak garam pemilik lahan, melainkan melakukan permainan "di luar pentas" melalui tindakan yang disengaja dalam aktivitas sehari-hari mereka sebagai petambak penggarap dengan cara-cara yang tersamar dalam menghasilkan produk garam yang tidak berkualitas (Rochwulaningsih, 2006). Dengan demikian, pola perlawanan yang ditempuh petambak garam penggarap tersebut memiliki kecenderungan mirip dengan apa yang dikemukakan oleh Scott, yaitu berupa perlawanan sehari-hari yang menghindarkan konfrontasi dan cenderung melakukan penghindaran maupun penyamaran (Scott, 1983). Meskipun apa yang dilakukan oleh petambak garam penggarap itu dapat 
dikategorikan sebagai tindakan "tidak jujur” yang terkait dengan kegiatan industri (malfeasance), karena melakukan tindakan penghindaran untuk menghasilkan produk yang baik, tetapi itu manifestasi dari adanya perlawanan sehari-hari yang sangat "soft"dan merupakan senjata dari kaum lemah terhadap tekanan struktural dari petambak garam pemilik lahan.

Pada dasarnya persoalan rendahnya kualitas garam rakyat tidak semata-mata disebabkan oleh faktor sosial dalam pola hubungan produksi yang tidak berkeadilan antara petambak garam pemilik lahan dengan petambak garam penggarap, tetapi juga faktor ekonomi. Secara teknis, untuk dapat menghasilkan garam yang berkualitas diperlukan rentang waktu tertentu sesuai standar, yang ideal yaitu > 10 hari baru dipanen. Dalam hal ini petambak garam penggarap mengaku, bahwa mereka pada umumnya memanen garam dalam rentang waktu $<10$ hari. Dari 98 responden petambak garam, $85.05 \%$ memanen garam dalam usia 2-5 hari dan $14.05 \%$ memanen dalam usia 6-8 hari. Ternyata dari $85.05 \%$ itu semuanya adalah petambak garam penggarap, sedangkan $14.05 \%$ adalah petambak garam pemilik lahan sempit yang membuat garam secara mandiri di lahannya sendiri (Rochwulaningsih, 2012: 114-115). Dengan demikian dikalangan petambak garam penggarap, terdapat kecenderungan memanen garam dalam usia lebih pendek dibandingkan petambak garam pemilik lahan. Argumen sederhana yang disampaikan petambak garam penggarap yang memanen garam dalam usia 2-5 hari karena membutuhkan uang chas dengan segera untuk memenuhi kebutuhan makan keluarganya, sedangkan yang memanen dalam usia 6-8 hari lebih terkait motif untuk dapat meraih keuntungan atau hasil panen lebih besar dan tindakan itu bisa diambil karena petambak pemilik lahanyang mengerjakan lahannya sendiri masih memiliki otoritas untuk menjual garam produknya.

\section{Aksi Ngoret di Ladang Garam}

Pada komunitas petambak garam terdapat kebiasaan mengambil sisa-sisa hasil panen garam di ladang yang dilakukan oleh orang-orang tertentu dan biasanya perempuan. Kegiatan untuk mengambil sisa-sisa hasil panen garam di ladang garam itu dalam tulisan ini disebut dengan istilah aksi ngoret. Aksi ngoret (di beberapa daerah dengan nama lain) di ladang garam adalah fenomena umum yang dapat ditemukan pada komunitas petambak garam di Indonesia khususnya di Jawa. Sekilas aksi itu tampak semata-mata hanya sekedar untuk mendapatkan hasil dengan mengais sisa-sisa garam yang tercecer di lahan setelah dipanen. Jadi itu salah satu cara orang miskin untuk mendapatkan sumber kehidupan. Akan tetapi dari penelitian ditemukan fakta bahwa aksi ngoret pada dasarnya dapat dimaknai tidak sekedar untuk mendapatkan penghasilan, melainkan merupakan salah satu bentuk perlawanan sehari-hari yang dilakukan oleh petambak garam penggarap dan buruh angkut terhadap ketidak-adilan dan adakalanya keseweng-wenangan para pemilik lahan yang dipandang memberi upah dan atau bagi hasil yang rendah dengan aneka macam potongan dan pola pembayaran yang bertempo. Berikut ini disampaikan paparan bagaimana dan mengapa aksi ngoret itu eksis dan berkembang pada komunitas petambak garam. Paparan ini didasarkan pada observasi dan wawancara mendalam dengan pengoret, buruh angkut, petambak penggarap, petambak pemilik lahan dan mandor yang berlangsung di lahan-lahan garam dan di gudanggudang di lokasi penelitian.

Pada komunitas petambak garam terdapat aksi "mencuri yang disamarkan" yang pada dasarnya terkait dengan aktivitas buruh khususnya buruh angkut garam yang eksistensinya sulit untuk diberantas yaitu yang disebut aksi ngoret yang berarti mengais sisa-sisa hasil panen garam.Adapun orang yang melakukan aksi itu disebut pengoret atau pengasak, istilah yang diberikan petambak garamsetempat untuk 
menyebut mereka yang mencari sisa-sisa atau mengais sisa garam hasil panen yang berceceran di area lahan tambak garam. Para pengoret umumnya adalah kaum perempuan paroh-baya usia 25-40 tahun, bergerombol lengkap dengan penutup kepala dan selendang, layaknya model wanita petambak pada umumnya. Peralatan yang menyertai mereka adalah sapu lidi kecil untuk menyapu sisa-sisa garam, serok, timba atau engkrak, dan karung atau sak ukuran $25-50 \mathrm{~kg}$.

Mereka biasanya berkelompok, berangkat pagi-pagi sekali bersama-sama para petambak penggarap maupun buruh angkut garam yang merupakan keluarga atau tetangga mereka sendiri. Setiap pagi pada musim panen garam, mereka dengan menggunakan sarana transportasi berupa sepeda onthel bersama-sama menuju lahan garam yang sama. Dalam hal ini setiap pagi dan sore tampak terdapat pemandangan adanya "konvoi" iring-iringan sepeda onthel menuju lahan garam di desa-desa pantai. Kasus di wilayah Kabupaten Rembang, berdasarkan pengakuan beberapa pengoret, mereka berasal dari beberapa desa agraris di wilayah kecamatan Kaliori sebelah timur antara lain dari desa Babadan dan Pengkol yang sekaligus merupakan tempat asal dari sebagian petambak garampenggarap dan buruh angkut. Sesampainya di lahan, didapat pemandangan mereka bersama dengan masing-masing buruh angkut menuju gundukan-gundukan garam yang telah ditumpuk oleh petambak penggarap.

Pengoret biasa memulai aksinya, ketika para buruh angkut hampir selesai mengangkuti hasil panen dari setiap gundukan garam untuk dibawa di gudang yang telah disediakan. Mereka akan memulai menyapu sisa-sisa garam yang tampaknya sengaja disisakan oleh buruh angkut, di-serok, dimasukkan ke dalam timba untuk kemudian dimasukkan lagi ke dalam karung atau sak yang sudah disiapkan. Begitu seterusnya selalu mengikuti buruh angkut berpindah dari satu gudukan garam ke gundukan garamberikutnya. Setelah karung terisi penuh, pengoret kemudian mengikat karung tersebut untuk kemudian memanggul karung yang sudah dipenuhi garam itu dengan menggunakan selendang menuju ke tepi jalan besar. Terkadang karena isi karung yang begitu berat, adakalanya mereka saling bergantian membantu teman yang lain jika mereka kesulitan mengangkat karung tersebut. Mereka tampak penuh kebersamaan, rukun, saling bekerjasama dan tolong menolong, tidak ada persaingan apalagi konflik diantara mereka, karena mereka sama-sama menyadari sebagai kaum lemah, kaum marjinal yang mencari sumber penghidupan di lahan tambak garam.

Selesai di petak pertama, mereka pun melanjutkan aksinya ke petak yang lain mengikuti perpindahan buruh angkut garam dengan tetap membawa peralatan untuk ngoret dan karung atau sak yang telah dipersiapkan. Demikian seterusnya selalu berpindah mengikuti irama kerja buruh angkut yang berlangsung hampir sepanjang hari dalam kondisi normal rata-rata pukul 07.00-16.00. Setelah pekerjaan buruh angkut selesai, maka pengoret juga mengakhiri aksinya. Buruh angkut selanjutnya ke gudang untuk mengecek jumlah hasil kerja hari itu pada mandor yang mencatat, sedangkan pengoret membawa hasil koretannya kepada penadah atau bakul yang memang sudah setia menunggu mereka di gudang-gudang sekitar lokasi. Mereka (pengoret) beriringan membawa hasil koretan, masing-masing sekitar 3-4 karung diangkut sepeda dengan didorong. Setelah ditimbang dan dibeli dengan haarga lebih rendah dari harga pasar (dengan alasan kualitas jelek), mereka langsung mendapatkan uang cash sekitar Rp.25.000 hingga Rp.30.000,-. Dengan proses seperti itu, biasanya mereka tiba kembali di rumah masing-masing sekitar pukul 17.00.

Secara ekonomi dari sisi pekerja (penggarap dan buruh angkut), aksi pengoret mempunyai makna penting bagi kehidupan rumah tangga mereka, karena dapat menjadi sumber pendapatan lain yang sangat dibutuhkan dimasa krisis di mana tidak memungkinkan untuk budidaya pertanian. 
Sebagaimana telah disinggung, pengoret pada umumnya juga anggota keluarga (istri) atau tetangga petambak garam penggarap dan buruh angkut. Dalam hal besarnya hasil yang diperoleh jika dibandingkan dengan petambak penggarap dan buruh angkut, pengoret secara nominal memang lebih kecil. Selain memiliki makna ekonomi yang cukup penting bagi rumah tangga kaum marjinal, ngoret tampaknya merupakan bentuk perlawanan kaum marjinal (pekerja pembuat garam) terhadap pemilik lahan atas sistem bagi hasil dan pengupahan yang dirasakan pekerja tidak adil dan eksploitatif. Kaum pekerja (petambak penggarap dan buruh angkut) karena tidak memiliki posisi tawar, cenderung dikondisikan sebagai pihak lemah yang harus menerima bagi hasil maupun upah seperti yang dikehendaki pemilik lahan. Dalam hal ini secara struktural pekerja tersebut jelas berada dalam dominasi para pemilik lahan. Dengan penghasilan yang relatif rendah, pada tahun 2015 rata-rata Rp.40.000,- hingga Rp. 50.000,- petambak penggarap dan buruh angkut, jelas tidak sebanding dengan curahan tenaga dan waktu bekerja selama 8-9 jam, ditambah lagi sistem pembayaran yang bertempo. Selain itu dalam proses untuk sampai pada besaran upah yang relatif rendah tersebut, juga berlangsung praktek hubungan kerja yang manipulatif dan eksploitatif. Sebagaimana pernah dibahas di atas, bahwa sistem bagi hasil maro normatifnya dibagi dua separoh untuk pemilik lahan dan separoh penggarap. Namun demikian, dalam praktenya bagian penggarap dikurangi lagi untuk penggunaan diesel BBM, penyusutan, dan lain-lain serta nilai jual dibawah harga umum, sehingga jika dibuat rata-rata pendapatan perhari ketemu nominal seperti diatas. Demikian juga dengan buruh angkut, meskipun telah disepakati upah Rp.25,- per kg tetapi dipotong $10 \%$ untuk penyusutan karena tercecer, dimana 44 pikul setara dengan $2200 \mathrm{~kg}$ garam yang diangkut hanya diperhitungkan $2000 \mathrm{~kg}$ yang diberi upah, sehingga upah yang diperoleh rata-rata $\mathrm{Rp}$. 50.000,-/hari.
Hubungan kerja buruh-majikan yang penuh warna ketidak-adilan dan eksploitasi tersebut, sangat dirasakan dan disadari kaum buruh yang lemah tidak memiliki sumberdaya untuk melakukan perlawanan secara terbuka dan frontal. Dengan aksi ngoret yang pada hakekatnya merupakan "pencurian yang disamarkan", mereka berusaha berebut kembali bagian keuntungan dari upah minimal yang semestinya menjadi haknya. Dapat diketahui bahwa hasil ngoret sehari rata-rata 3-4 karung (175-200 kg) hampir setara dengan 10 $\%$ dari hasil kerja buruh angkut sehari yang dipotong tersebut (2200 hanya dihitung $2000 \mathrm{~kg}$ ), juga $10 \%$ yang dipotong dari hasil kerja buruh perombong. Dari pengamatan lapang dapat diketahui, bahwa di dua desa ladang garam terdapat 5 rombongan pengoret dan masingmasing terdiri dari 6 orang yang melakukan aksinya di lahan milik 6 orang majikan. Dengan demikian jumlah produk garam yang diambil pengoret mencapai sekitar $5250 \mathrm{~kg}$ per hari dan jika dibandingkan dengan jumlah total produksi garam di kedua desa itu sekitar $400.000 \mathrm{~kg}$, maka produksi garam yang direbut kembali kaum lemah melalui aksi ngoret ini tidak begitu besar hanya sekitar $1.31 \%$.

Sebagaimana diakui oleh beberapa petambak pemilik lahan, bahwa pada dasarnya aksi ngoret itu termasuk kategori kriminal karena perbuatan "mencuri yang disamarkan" yang juga sangat menganggu proses produksi bahkan dengan mata telanjang tampak mengurangi jumlah produksi. Dalam praktiknya, petambak penggarap dan buruh angkut tidak begitu peduli atau kadang dengan sengaja menyisakan dan tidak mengambil secara bersih garam-garam di ladang yang harus diangkut ke gudang. Itu jelas merupakan tindak kriminal pencurian tersamar menggerogoti hasil produksi yang sangat merugikan pihak pemilik lahan, meskipun demikian mereka tidak dapat serta merta memproses itu sebagai tindak kriminal pencurian. Mandor yang diberi tugas untuk mengatasi hal itu juga tidak dapat berbuat banyak, jika bertidak keras akan dianggap tidak 
berperikemanusiaan pada sesama pekerja, sehingga cenderung dibiarkan karena sama-sama mencari makan sekedar untuk dapat bertahan hidup.

Dengan demikian dapat dikemukakan, bahwa aksi ngoret termasuk salah satu bentuk perlawanan sehari-hari kaum lemah (petambak garam penggarap dan buruh angkut garam) berupa “pencurian yang disamarkan”. Hal ini tampaknya terkait dengan kondisi objektif kelompok sosial ini yang tidak memiliki sumberdaya sebagai senjata, sehingga salah satu tipikal perlawanan sehari-hari yang biasa mereka lakukan menghindarkan konfrontasi yang masif dan menantang serta cenderung melakukan penghindaran maupun penyamaran yang sama masifnya tapi seringkali jauh lebih efektif. Dengan meminjam konsep Scott (1983), aksi itu merupakan pergulatan yang prosais tetapi tetap dan rutin antara kaum buruh dengan majikan yang berusaha mengeruk keuntungan maksimum melalui penghisapan tenaga buruh dengan upah minimal. Persoalan menjadi menarik dimana petambak garam penggarap dan buruh angkut yang terlibat dalam hubungan kerja dengan majikan (pemilik lahan) dalam proses produksi industri garam ini justru melakukan perlawanan dengan menempuh cara melalui pencurian yang disamarkan. Padahal fenomena perlawanan buruh industri, pada umumnya didominasi oleh corak yang radikal dan konfrontatif. Kondisi itu tampaknya tidak terlepas dari fakta, bahwa sebagian besar $(>50 \%)$ petambak garam penggarap dan buruh angkut berasal dari pedesaan agraris, sehingga karakter budaya agraris berpengaruh terhadap cara-cara pensikapan mereka terhadap realitas hidup yang dijalani. Relevan dengan temuan Scott (1983) bahwa di beberapa desa di Asia Tenggara, petani miskin melakukan perlawanan sehari-hari terhadap tuan tanah dengan pola penghindaran, menjauhkan dari pola konfrontasi dan massal karena berdasarkan sejarahnya cara-cara yang konfrontatif dan radikal lebih mudah dibinasakan dan tidak memberi perubahan signifikan terhadap kehidupan petani miskin itu sendiri.

\section{SIMPULAN}

Dari pembahasan tersebut dapat dibuat simpulan, bahwa terdapat corak atau bentuk perlawanan yang dilakukan petambak garam penggarap maupun buruh pengangkut garam terhadap dominasi dan eksploitasi pemilik lahan tambak garam. Dalam hal ini perlawanan yang dilakukan cenderung berupa perlawanan sehari-hari yang tidak terbuka, menghindari konfrontasi dan cenderung melakukan penghindaran maupun penyamaran. Antara lain direpresentasikan pada contoh kasus di mana petambak garam penggarap kurang memiliki komitmen pada upaya pembuatan garam yang berkualitas yang dianggap hanya akan lebih menguntungkan pemilik lahan dari pada dirinya sebagai penggarap. Bahkan tidak jarang tindakan para petambak penggarap ini dengan sengaja, tetapi secara tersamar menjatuhkan kualitas garam yang dibuatnya. Selain itu, pada kasus aksi ngoret merupakan manifestasi dari adanya tindakan "pencurian yang disamarkan” yang sengaja dilakukan sebagai bagian dari bentuk perlawanan terhadap ketidakadilan pemilik lahan.

Dengan corak perlawanan tersebut, maka bentuk perlawanan petambak garam secara umum masih sangat sederhana dan fragmentaris jauh dari makna suatu gerakan perlawanan yang sesungguhnya. Dengan corak perlawanan seperti itu, maka hasil yang dapat dicapai dari gerakan perlawanan yang dilakukan petambak garam penggarap dan buruh angkut garamselama ini tidak tampak dipermukaan bahkan tampak tidak eksis. Oleh karena itu, hasil yang dicapai juga belum begitu signifikan untuk menghadapi dominasi dan eksploitasi dari pihak pemilik lahan. Namun demikian ke depan gerakan perlawanan yang telah dilakukan petambak garam maupun buruh angkut garam yang tercermin dalam bentuk 
tipologi tersebut pada dasarnya memiliki potensi untuk dikembangkan dalam format gerakan perlawanan yang progresif dengan memadukan dan mensinergikan keterlibatan pihak luar yang memiliki sumberdaya.

\section{REFERENSI}

Chayanov, Alexander (1991). The Theory of Peasant Cooperative. London and New York: I.B. Tauris.

De Jonge, (1993). Monopolization and Resistance: State and Salt Producers in Madura. Bangkok: Prince of Songkla University Press.

Departemen van Binnenlandsch Bestuur. 1932. Het Zoutmonopolie. Handleiding Ten Dienste Van De Inlandsche Bestuursambtenaren. Batavia-Centrum : Volkslectuur.

Effendy, Fery, 2012. Konflik Perebutan Lahan Antara Masyarakat Dengan PT. Garam di Desa Pandan Kec. Galis Kab,. Pamekasan. Madura. Skripsi pada Program Studi Sosiologi Fakultas Ilmu Sosial dan Ilmu Budaya Universitas Trunojoyo.

Fitriya, Umi. 2012. Perkembangan Usaha Garam Rakyat dan Peranan Perempuan. Studi Kasus di Kec. Kalianget Kabupaten Sumenep Madura 1975-1999. Tesis pada Program Magister Ilmu Sejarah Pascasarjana Universitas Diponegoro.

Garraghan, Gilbert J. 1957. A Guide To Historical Method. New York: Fordham University Press.

Granovetter, Mark. 1985. Economic of Action and

Social Structure: The Problem of Embeddedness. American Journal of Sociology Vol. 91, p. 481-510.

Knaap, G.J. 1991. "A Forgotten Trade: Salt in Southeast Asia 1670-1813", dalam Gerrit J. Knaap, Luc Nagtegaal \& Roderich Ptak (eds), Emporia, Commodities and Entrepreneurs in Asian Maritime Trade, C. 1400-1750. Wiesbaden : Steiner.
Kuntowijoyo. 1988. Perubahan Sosial Dalam Masyarakat Agraris: Madura 1850-1940. Disertasi pada Fakultas Sastra Universitas Gajah Mada

Rochwulaningsih, Yety 2012. Marjinalisasi Garam Rakyat. Semarang: CV. Madina Press.

------ 2006. Surviving Strategies of Salt Farmer Under the Pressure of Global Economic Expansion: Case on Salt Farmer in Rembang Central Java. Presented in International Seminar on Development and Changers of Culture. Asian Cultures Research Institut of Toyo University. Tokyo 13-14 November 2006.

---------- 2007. Petani Garam dalam Jeratan Kapitalisme: Analisis Kasus Petani Garam di Rembang Jawa Tengah. Jurnal Masyarakat Kebudayaan dan Politik. Vol. XX.

Roth, Guenther and Wittich, Claus (ed.). 1978. Max Weber Economy and Society. An Outline of Interpretive Sociology. Vol 1 \& 2. Berkeley-Los Angeles-London: University of California Press.

Sanders, Martin. 1968. Report On The Government Owned Salt Industry In Indonesia. Jakarta: Koleksi KITLV.

Scokpol, Theda (ed.). 1984. Vision and Method in Historical Sociology. New York: Cambridge University Press.

Scott, James C. 1983. Weapon of the Weak. Everyday Forms of Peasant Resistancein SouthEast Asia. New Haven \& London: Yale University. 
